\title{
Global chronostratigraphical correlation table for the last 2.7 million years
}

1 Cambridge Quaternary, Department of Geography, University of Cambridge, Cambridge CB2 3EN, England.Email:plg1@hermes.cam.ac.uk 2 Utrecht Centre of Geosciences, Department of Physical Geography, Utrecht University, P.O.Box 80.115, 3508TC Utrecht, The Netherlands.

\begin{abstract}
The table provides a correlation of chronostratigraphical subdivisions of late Cenozoic geological time, spanning the last 2.7 million years. The formal division of the Quaternary is the responsibility of the International Commission on Stratigraphy's (ICS) Subcommission on Quaternary Stratigraphy (SQS), in partnership with the International Union for Quaternary Research's (INQUA) Commission on Stratigraphy and Chronology (SACCOM). This is the third published version of the chart. Earlier versions are Gibbard et al., 2004, 2005. See http://www.quaternary.stratigraphy.org.uk/correlation/ for history.
\end{abstract}

\section{Chronostratigraphy and the base of the Quaternary}

The timescale is based on the internationally-recognised formal chronostratigraphical/geochronological subdivisions of time: the Phanerozoic Eonathem/Eon; the Cenozoic Erathem/Era; the Quaternary System/Period; the Pleistocene and Holocene Series/Epoch, and finally the Early/Lower, Middle, Late/Upper Pleistocene Subseries/Subepoch. At present the Subseries (Subepoch) divisions of the Pleistocene are being formalised. Series, and thereby systems, are formally-defined based on Global Stratotype Section and Points (GSSP) of which two (Holocene and Pleistocene Series) have been ratified for the Quaternary System. The currently ratified base of the Pleistocene is defined in a GSSP at Vrica in Southern Italy, (Aguirre and Pasini, 1985), with an age of $\sim 1.8 \mathrm{Ma}$. However, it is proposed to define the base of the Quaternary/Pleistocene at 2.58 million years from Monte San Nicola, also in southern Italy, which is the current GSSP for the Pliocene Gelasian Stage (Rio et al., 1994, 1998).

Since 1948 there has been a consensus that the boundary should be placed at the first evidence of climatic cooling of ice-age magnitude. This was the original basis for placing the boundary at $\sim 1.8 \mathrm{Ma}$ in marine sediments at Vrica in Calabria, in Italy (Aguirre \& Pasini, 1985). It is now known that a major cooling occurred earlier, at c. 2.55 million years in the Mediterranean (Cita, this issue), and even earlier cooling events are known from the Pliocene. Since its definition at 1.8 Ma there has been strong pressure for the basal Quaternary/Pleistocene boundary to be moved downwards to better reflect the initiation of major global cooling (Pillans and Naish, 2004; Gibbard et al., 2005; Bowen \& Gibbard, 2007), effectively corresponding to the Gauss/Matuyama magnetic Chron boundary (e.g., Partridge, 1997; Suc et al., 1997). See discussion in this volume (Ogg \& Pillans, Head et al., Lourens)

At the time of publication discussions concerning the position of the boundary(ies) are at an advanced stage. The formal boundary of the Quaternary/Pleistocene at 1.8 million years is indicated but the proposal to define formally the base of the Quaternary from that of the Pleistocene, at the 2.6 million-year boundary, has already been accepted following formal voting by the ICS. The proposal is awaiting formal ratification by the IUGS. It is expected a decision will be made following the International Geological Congress to be held in Oslo in August 2008.

Similarly there is uncertainty about the status of the term Tertiary (Head et al., this issue). Like the Quaternary, it has often been regarded as a full System/Period (Salvador, 2006a, b) but discussions are in progress on whether the Neogene and Paleogene should be reclassified as sub-systems/sub-periods.

The chart extends to 2.7 million years to include the very end of the preceding Piacenzian Stage of the Pliocene Series.

\section{Pleistocene GSSPs}

Formal GSSPs for the Pleistocene Subseries will be proposed in the near future. The INQUA Commission on Stratigraphy/ICS Working Group on Major Subdivision of the Pleistocene agreed to place the Early/Lower-Middle boundary at the Brunhes/Matuyama magnetic reversal Chron boundary (Richmond, 1996). A stratotype locality has yet to be identified, but three candidate sections are being considered by SQS Working Group (Head et al., this issue). Following recent re-evaluation, the Middle-Late/Upper boundary is placed, following historical precedent in NW Europe, at the Saalian-Eemian Stage boundary. The former is positioned at the basal-boundary stratotype of the Eemian in the Amsterdam-Terminal borehole, the Netherlands (Gibbard, 2003; Litt \& Gibbard, this issue).

The Holocene is generally regarded as having begun 10,000 radiocarbon years before $1950 \mathrm{AD}$, or $11.7 \mathrm{k}$ calendar years before 2000 AD (Wolff, 2008). This boundary has been defined as a Global Stratotype Section and Point (GSSP; Walker et al., this issue) in the North-GRIP ice core of the Greenland Ice-Core Project (NGRIP: Rasmussen et al., 2006). Auxillary stratotypes are also defined, for example, in an annually-laminated lake sequence in western Germany (Litt et al., 2001).

\section{Marine stage/zone divisions}

Isotope studies from the bottom sediments of the world's oceans have indicated that as many as 52 cold and interspersed warm climate periods, often referred to as glacials and interglacials, occurred during the last 2.6 million years. In contrast to the deep sea, continental evidence is so incomplete and regionally variable that terrestrial glacial-interglacial stratigraphies must refer to the ocean record for a global chronological foundation.

Here the deep-sea based, climatically-defined chronostratigraphy is taken from oxygen isotope data collected and processed by Crowhurst (2002), updated by Tzedakis et al. (2006). It is plotted against the magnetostratigraphic time scale prepared and modified from Funnell (1996). The curve plots depict $\delta^{18} \mathrm{O}$ (the ratio of ${ }^{18} \mathrm{O}$ versus ${ }^{16} \mathrm{O}$ ) in the tests of fossil benthonic (ocean-floor dwelling) foraminifera. Shifts in this ratio are a measure of global ice-volume, 


\section{Global chronostratigraphical correlat}

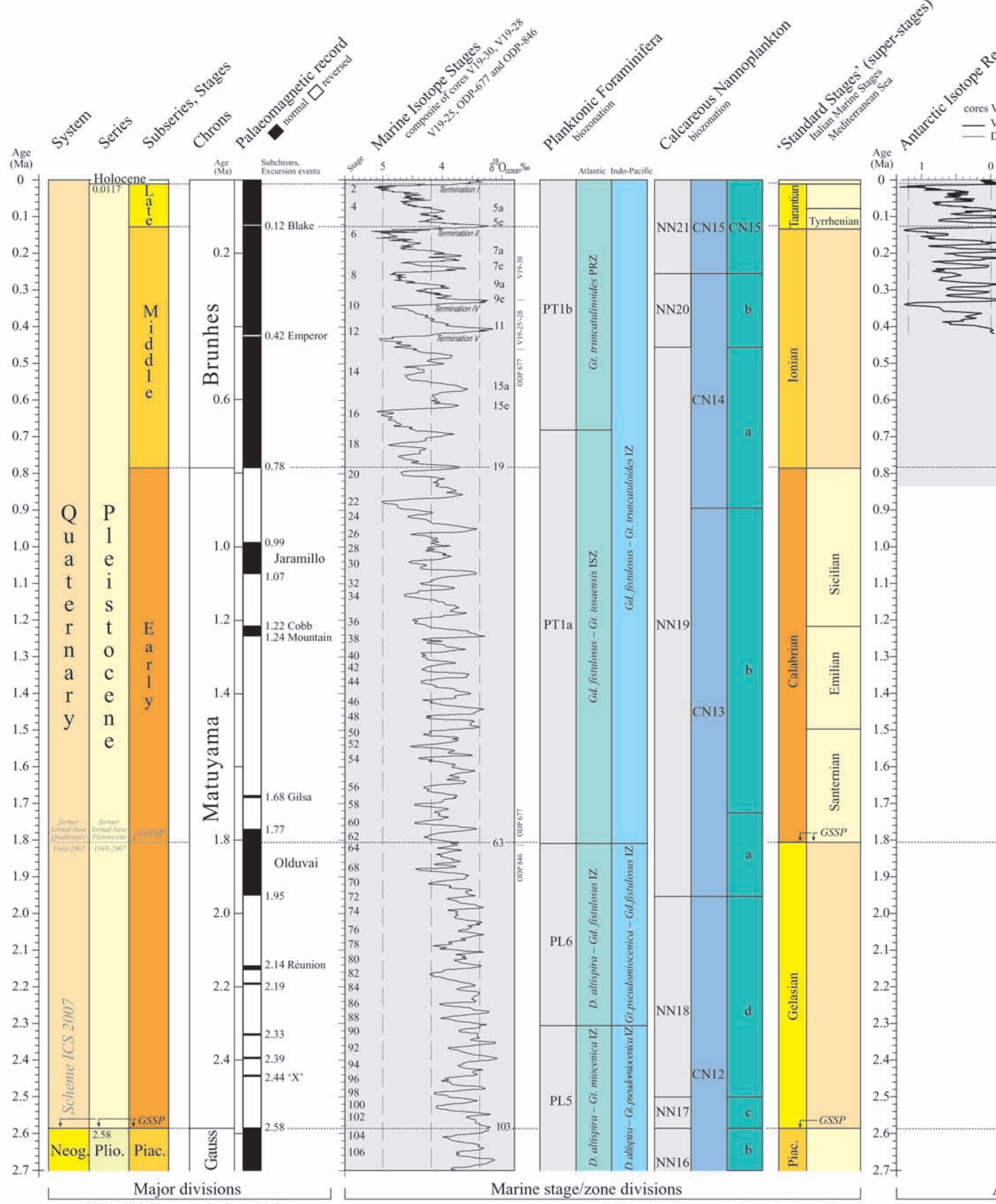

GSSP $=$ Global Stratotype Section and Point 
which is dependent on global temperature and which determines global sea-level. Planktonic foraminifera and calcareous nannoplankton provide an alternative biostratigraphical means of subdivision of marine sediments. The micropalaeontological zonation is taken from Berggren et al. (1995).

\section{'Standard stage' ('super-stage') global divisions}

The desire to divide Quaternary/Pleistocene time into 'standard stages', that is units of approximately the same duration as those in the pre-Quaternary Tertiary time, has been advocated on occasions. The only succession that has been divided in this way is the shallow marine sequences in the Mediterranean region, especially in southern Italy, based principally on faunal and protist biostratigraphy. For various reasons the scheme was considered unsatisfactory for use beyond this region. Renewed investigation in recent years has led to the proposal of units based on multidisciplinary investigation. The Italian shallow marine stages are derived from Van Couvering (1997) modified by Cita et al. (2006 and Cita, this issue).

In view of their duration, encompassing multiple climate cycles and periods for which regional stage units of markedly shorter duration have been defined, these 'standard stages' are considered as 'super-stages'.

\section{Major continental records: Antarctic ice, Chinese Loess, Lake Baikal}

Two plots of isotope measurements from Antarctic ice-cores are shown. The first is the $420 \mathrm{ka}-$ long plot from the Vostok core and shows atmospheric $\delta^{18} \mathrm{O}$ (Petit et al., 1999), determined from gas bubbles in the ice. This atmospheric $\delta^{18} \mathrm{O}$ is inversely related to $\delta^{18} \mathrm{O}$ measurements from seawater and therefore is a measure of ice-volume. It can also be used to separate ice volume and deepwater temperature effects in benthic foraminiferal $\delta^{18} \mathrm{O}$ measurements. The deuterium measurements $(\delta D)$ for the last $800 \mathrm{ka}$ are from the $3.2 \mathrm{~km}$ deep EDC core in Dome C (EPICA community members, 2004; Jouzel et al., 2007). They come from samples of the ice itself and give a direct indication of Antarctic surface palaeotemperature.

For the Chinese loess deposits the chart shows the sequence of palaeosols (indicated by S and WS) and alternating loess units (L and WL) from Luochuan (An et al., 1990). It is accompanied by a continuous plot of magnetic susceptibility from the same sequence.

The Siberian Lake Baikal provides a bioproductivity record from the heart of the world's largest landmass, an area of extreme continental climate. High concentrations of biogenic silica indicate high aquatic production during interglacials (i.e., lake diatom blooms during ice-free summer seasons). The composite biogenic silica record from cores BDP-96-1, -96-2 and -98 is plotted on an astronomically tuned age scale (Prokopenko et al., 2006). The composite record extends well beyond the top of the Olduvai reversal, a tuned age scale for this part of the series is in preparation.

\section{Regional stage/substage divisions}

The continuous sequences, above, provide the comparison for a selection of continental and shallow marine stage-sequences from around the world reconstructed from discontinuous sediment successions. Solid horizontal lines on the plots indicate observed boundaries, where no lines separate stages, additional events may potentially be recognised in the future.

The NW European stages are taken from Zagwijn (1992) and De Jong (1988). The British stages are taken from Mitchell et al.
(1973); Gibbard et al. (1991) and Bowen (1999). The Russian Plain stages are taken from the Stratigraphy of the USSR: Quaternary System (1982, 1984), Krasnenkov et al. (1997), Shik et al. (2002), Iossifova (pers. comm.) and Tesakov (pers. comm). In addition, the Russian Pleistocene is also frequently divided into the Eopleistocene, equivalent to the Early Pleistocene Subseries, and the Neopleistocene, equivalent to the Middle and Late Pleistocene Subseries. The North American stages are taken from Richmond (unpublished). The New Zealand stages are from Pillans (1991) and Beu (2004).

\section{Anthropocene}

A recent proposal has been made to establish a new series status division following the Holocene, to be termed the Anthropocene. The term is being increasingly employed to identify the current interval of anthropogenic global environmental change, and may be adopted on stratigraphical grounds. It might be adopted at formal Series/Epoch level, for the time since the start of the Industrial Revolution when changes sufficient to leave a global stratigraphic signature distinct from that of the Holocene or of previous Pleistocene interglacial phases, occurred. A boundary definition may be made either using a Global Stratigraphic Section and Point ('golden spike') localities, and or by adopting a numerical date (Global Standard Stratigraphic Age: GSSA). Formal adoption of this term depends on its utility, particularly to Earth Scientists working on late Holocene successions (Zalasiewicz et al., 2008). Because of its' short time duration, it has not been included in the chart.

\section{References}

Aguirre, E. \& Pasini, G. 1985 The Pliocene-Pleistocene boundary: Episodes, 8, pp. 116-120.

An Zhisheng, Lui Tungsheng, Porter, S.C., Kukla, G., Wu Xihao and Hua Yingming 1990 The long-term paleomonsoon variation record by the loess-paleosol sequence in central China: Quaternary International 7/8, pp. 91-95.

Berggren, W.S., Hilgen, F.J., Langereis, C.G., Kent, D.V., Obradovich, J.D., Raffi, I., Raymo, M.E. and Shackleton, N.J. 1995 Late Neogene chronology: new perspectives in high-resolution stratigraphy: Geological Society of America Bulletin, 107, pp. 1272-1287.

Beu, A.G., 2004. Marine mollusca of oxygen isotope stages of the last 2 million years in New Zealand. Part 1: Revised generic positions and recognition of warm-water and cool-water immigrants: Journal of the Royal Society of New Zealand, 34, pp. 111-265.

Bowen, D.Q. 1999. A revised correlation of the Quaternary deposits in the British Isles. Geological Society Special Report no.23.

Bowen, D.Q. \& Gibbard, P.L. 2007 The Quaternary is here to stay: Journal of Quaternary Science, 22, pp. 3-8.

Cita, M.B., Capraro, L., Ciaranfi, N., Di Stephano, E., Marino, M., Rio, D., Sprovieri, R. and Vai, G.B., 2006. Calabrian and Ionian: A proposal for the definition of Mediterranean stages for the Lower and Middle Pleistocene: Episodes, 29, pp. 107-113.

Crowhurst, S.J. 2002 Composite isotope sequence. The Delphi project http://www.esc.cam.ac.uk/new/v10/research/institutes/godwin/body.html.

De Jong, J. 1988: Climatic variability during the past three million years, as indicated by vegetational evolution in northwest Europe and with emphasis on data from The Netherlands. Philosophical Transactions of the Royal Society of London B 318, pp. 603-617.

EPICA members 2004 Eight glacial cycles from an Antarctic ice core: Nature, 429, pp. 623-628.

Funnell, B.W. 1996. Plio-Pleistocene palaeogeography of the southern North Sea Basin. (3.75-0.60 Ma): Quaternary Science Reviews 15, pp. 391-405.

Gibbard, P.L 2003 Definition of the Middle/Upper Pleistocene boundary: Global and Planetary Change, 36, pp. 201-208.

Gibbard, P.L., West, R.G. \& Zagwijn, W.H. (editors) 1991 Early and early Middle Pleistocene correlations in the southern North Sea Basin: Quaternary Science Reviews, 10, pp. 23-52.

Gibbard, P.L. Smith, A.G., Zalasiewicz, J.A., Barry, T.L., Cantrill, D., Coe, A.L., Cope, J.C.W., Gale, A.S., Gregory, F.J., Powell, J.H., Rawson, 
P.R., Stone, P. \& Waters, C.N. 2005 What status for the Quaternary?: Boreas, 34, pp. 1-12.

Gibbard, P.L., Cohen, K.M., Boreham, S. \& Moscariello, A. 2004. Global chronostratigraphical correlation table for the last 2.7 million years. Subcommission on Quaternary Stratigraphy, International Commission on Stratigraphy: Cambridge.

Gibbard, P.L., Boreham, S., Cohen, K.M. \& Moscariello, A. 2005 Global chronostratigraphical correlation table for the last 2.7 million years:Boreas, 34, 1 (inclusion).

Jouzel, J., Masson-Delmotte, V., Cattani, O., Dreyfus, G., Falourd, S., Hoffmann, G., Nouet, J., Barnola, J. M., Chappellaz, J., Fischer, H., Gallet, J. C., Johnsen, S., Leuenberger, M., Loulergue, L., Luethi, D., Oerter, H., Parrenin, F., Raisbeck, G., Raynaud, D., Schwander, J., Spahni, R., Souchez, R., Selmo, E., Schilt, A., Steffensen, J. P., Stenni, B., Stauffer, B., Stocker, T., Tison, J.-L., Werner, M. and Wolff, E. W. (2007): Orbital and millennial Antarctic climate variability over the last 800,000 years: Science, 317, pp. 793-796

Krasnenkov R.V., Iossifova Yu.I. \& Semenov V.V. 1997. The Upper Don drainage basin - an important stratoregion for climatic stratigraphy of the early Middle Pleistocene (the early Neopleistocene) of Russia. Quaternary geology and paleogeography of Russia. Moscow. Geosynthos, pp. 82-96. (Russian; abstract in English).

Litt, T., Brauer, A., Goslar, T., Merkt, K., Balaga, K., Müller, H., RalskaJasiewiczowa, M. Stebich, M. \& Negendank, J.F.W. 2001 Correlation and synchronisation of lateglacial continental sequences in northern central Europe based on annually laminated lacustrine sediments: Quaternary Science Reviews, 20, pp. 1233-1249.

Mitchell, G.F., Penny, L.F., Shotton, F.W., West R.G. 1973 A Correlation of Quaternary deposits in the British Isles: Geological Society of London Special Report, 4, 99 pp.

Petit, J.R., Jouzel, J., Raynaud, D., Barkov, N.I., Barnola, J.-M., Basile, I., Bender, M., Chappellaz, J., Davis, M., Delayque, G., Delmotte, M., Kotlyakov, V.M., Legrand, M., Lipenkov, V.Y., Lorius, C., Pépin, L., Ritz, C., Saltzman, E. \& Stievenard, M. (1999) Climate and atmospheric history of the past 420,000 years from the Vostok ice core, Antarctica: Nature, 399, pp. 429-436.

Partridge, T.C. (ed.) 1997a The Plio-Pleistocene boundary: Quaternary International, 40, pp. 1-100.

Partridge, T.C. 1997b Reassessment of the position of the Plio-Pleistocene boundary: is there a case for lowering it to the Gauss-Matuyama Palaeomagnetic reversal? In: Partridge, T.C. (ed.) 1997 The Plio-Pleistocene boundary. Quaternary International, 40, pp. 5-10.

Pillans, B. 1991 New Zealand Quaternary stratigraphy: an overview: Quaternary Science Reviews, 10, pp. 405-418.

Pillans, B. and Naish, T., 2004. Defining the Quaternary: Quaternary Science Reviews, 23, pp. 2271-2282.

Prokopenko, A. A., Hinnov, L. A., Williams, D. F., Kuzmin, M. I. 2006 Orbital forcing of continental climate during the Pleistocene: a complete astronomically-tuned climatic record from Lake Baikal, SE Siberia: Quaternary Science Reviews, 25, pp. 3431-3457.

Rasmussen, S. O., Andersen, K.K., Scensson, A.M., Steffensen, J.P., Vinther, B.M., Clausen, H.B., Siggaard-Andersen, M.-L., Johnsen, S.J., Larsen, L.B., Dahl-Jensen, D., Bigler, M., Röthlisberger, R. Fischer, H., Goto-Azuma, K., Hansson, M.E., Ruth, U. 2006. A new Greenland ice core chronology for the last glacial termination: Journal of Geophysical Research, 111. D06102.

Richmond, G.M. 1996 The INQUA-approved provisional Lower-Middle Pleistocene boundary. In: Turner C. The early middle Pleistocene in Europe. pp. 319-326, Balkema: Rotterdam.

Rio, D., Sprovieri, R., \& Di Stefano, E. 1994 The Gelasian Stage: a proposal of a new chronostratigraphic unit of the Pliocene Series. Rivista Italiano di Paleontoloqia e Stratigrafia 100, 103-124.

Rio, D., Sprovieri, R., Castradori, D., and Di Stefano, E. 1998 The Gelasian Stage (Upper Pliocene): A new unit of the global standard chronostratigraphic scale: Episodes, 91, pp. 82-87.

Salvador, A., 2006a. The Tertiary and the Quaternary are here to stay:AAPG Bulletin, 90, pp. 21-30.

Salvador, A., 2006b. A stable Cenozoic geologic time scale is indispensable: Episodes, v.29, pp.43-45.

Shik S.M., Borisov B.A., Zarrina E.P. 2002 About the project of the interregional stratigraphic scheme of the Neopleistocene of East European Platform and improving regional stratigraphic schemes. The Third All Russian Meeting on the Quaternary research. Abstracts. Geological Institute RAN -Smolensky Pedagogical University. Smolensk. pp. 125-129. (in Russian).

Stratigraphy of the USSR: Quaternary System (1982) volume 1, Moscow. Nedra. 443 pp. (in Russian).
Stratigraphy of the USSR: Quaternary System (1984) volume 2. Moscow. Nedra. 556 pp. (in Russian).

Suc, J.P., Bertini, A., Leroy, S.A.G. \& Suballyova, D. 1997 Towards a lowering of the Pliocene/Pleistocene boundary to the Gauss/Matuyama Reversal. In: Partridge, T.C. 1997 (ed.) The Plio-Pleistocene boundary. Quaternary International 40, pp. 37-42.

Tzedakis, P.C., Hooghiemstra, H. \& Pälike, H. (2006) The last 1.35 million years at Tenaghi Philippon: revised chronostratigraphy and long-term vegetation trends: Quaternary Science Reviews 25, pp. 3416-3430.

van Couvering, J. 1997 Preface, the new Pleistocene. In: van Couvering, J. (ed.) The Pleistocene boundary and the beginning of the Quaternary. University Press: Cambridge. ii-xvii.

Wolff, E.W. 2008 What is the "present"?: Quaternary Science Reviews, 26, pp. 3023-2024.

Zagwijn, W.H. 1992, The beginning of the Ice Age in Europe and its major subdivisions. Quaternary Science Reviews 11, pp. 583-591.

Zalasiewicz, J., Smith, A., Williams, M., Barry, T.L., Bown, P.R., Brenchley, P., Cantrill, D., Coe, A.L., Gale,A., Gibbard, P., F. Gregory,J., Hounslow, M., Knox, R., Marshall, J., Oates, M. Powell, J., Rawson, P., Stone, P. \& Waters, C. 2008 Are we now living in the Anthropocene?: GSA Today, 18, pp. 4-8.

Philip Gibbard is Professor of Quaternary Palaeoenvironments at the University of Cambridge, United Kingdom, and chair of the International Commission on Stratigraphy's Subcommission on Quaternary Stratigraphy. He is also a member, and was formerly Secretary, of the Stratigraphy and Geochronology Commission of INQUA, the INQUA Subcommission of European Quaternary Strati graphy and the Geological Society of London's Stratigraphy Commi ssion. His research is focused on terrestrial and shallow marine sedimentation, stratigraphy and environmental evolution throughout Europe, but he has also worked in the Arctic, North America and South-East Asia.

Kim M. Cohen (1973) is employed at Utrecht University, where he graduated (1998) and obtained his Ph.D. (2003) on the impact of differential subsidence to the buildup of the Holocene Rhine-Meuse Delta. After a stay abroad (Jena, Germany / Cambridge, U.K.), Kim returned to Utrecht to bridge between fluvial and coastal workers, geographers and geologists within the Utrecht Centre of Geosciences (2005-present). His interests include: Palaeogeography and sequence stratigraphy of the North Sea Basin last $500 \mathrm{ka}$; Neotectonics, glacioisostasy and eustacy in ice-sheet peripheral Europe; Fluvial archives and estimation palaeodischarge and sediment transfer. rates; GIS applications to reconstruct Quaternary Geology.
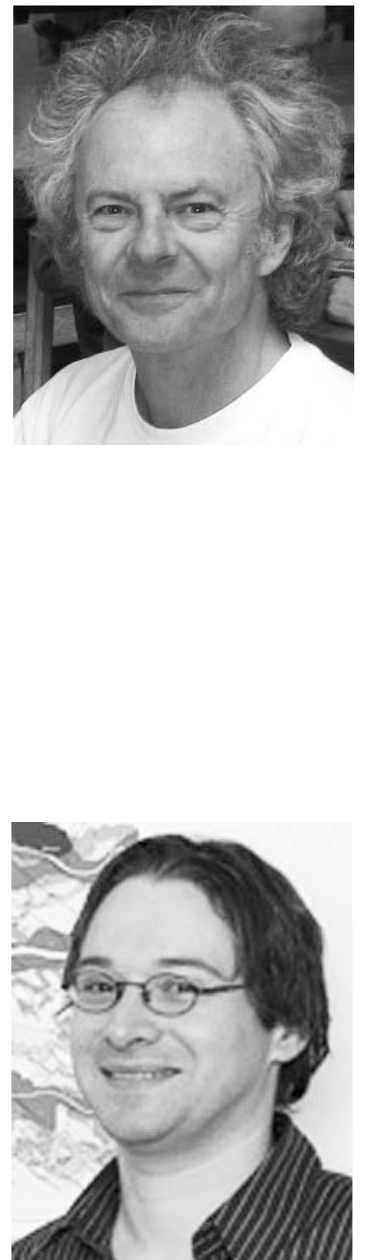